\title{
MEMBACA PERMULAAN MELALUI KEGIATAN MENEBALKAN HURUF
}

\author{
Oleh: \\ Risky Ramadani \\ SD Negeri 10 Terangun, Terangun, Gayo Lues \\ Email:moobee@yahoo.com
}

\begin{abstract}
Abstrak
Artikel ini mengenai membaca permulaan melalui kegiatan menebalkan huruf pada anak kelas 1 Sekolah Dasar Negeri 10 Terangun.Membaca permulaan pada anak - anak belum berkembang optimal.Anak - anak tidak bisa membedakan lambang huruf kemudian menuliskannya. Guru membutuhkan kegiatan yang menarik untuk mengoptimalkan perkembangan bahasa tersebut, yaitu kemampuan membaca permulaan. Kemampuan membaca permulaan melalui kegiatan menablkan huruf dipilih dan cenderung menarik, karena anak - anak bisa menuliskan ulang baik itu di buku tulis masing - masing maupun di papan tulis.Menebalkan huruf menggunakan warna - warna yang menarik menambah keinginan anak untuk belajar. Melalui menebalkan huruf, kemampuan membaca permulaan pada anak dapat berkembang secara optimal.Dari sepuluh siswa di kelas I, Sembilan diantaranya sudah dapat mengenal dan membedakan lambang huruf.
\end{abstract}

Kata kunci : membaca permulaan, menebalkan huruf, siswa kelas I SD N 10 Terangun

\begin{abstract}
The article discusses the improvement of early reading skill through thickening alphabet activity in the first grader of Sekolah Dasar Negeri 10 Terangun. Students' early reading was not optimally developed. They were unable to differentiate alphabet sign and write it. Teachers needed attractive activities to optimize the linguistic development, specifically the early reading skill. Developing the early reading skill through thickening alphabet was chosen and was interesting enough, because students could rewrite alphabet either on their own notebook or on the board. Thickening alphabet using colorful stationery could increase their willingness to study. Through this activity, the early reading skill could develop optimally. Out of ten students in the first grade, nine were able to recognize and differentiate alphabet sign.
\end{abstract}

Keywords: early reading, thicken alphabet, first grader of SD N 10 Terangan

\section{PENDAHULUAN}

Setiap individu anak usia dini memiliki karakteristik dan potensi yang berbeda beda. Anak usia dini menurut NAEYC (national Association for The Education of Young Children) adalah anak yang berusia antara 0 sampai 8 tahunyang mendapatkan layanan pendidikan di taman penitipan anak, penitipan anak dalam keluarga, pendidikan prasekolah baik negeri maupun swasta, taman kanak - kanak (TK) dan Sekolah Dasar. Potensi dan perkembangan pada anak usia dini harus difasilitasi dengan baik dan dioptimalkan melalui pendidikan.

Pendidikan anak usia dini dipandang sebagai suatu proses pendidikan di masa usia emas (the golden age)Harun Rasyid, dkk (2009: 43).Pada masa anak usia dini proses pertumbuhan dan perkembangan 
dalam berbagai aspek seperti fisik, sosialemosional, dan kognitif sedang mengalami masa yang tercepat dalam rentang perkembangan hidup manusia (Berk dalam Sofia Hartati 2005:5).Pendidikan pada masa tersebut sangat penting dalam kehidupan anak untuk memasuki tahapantahapan selanjutnya.

Guru dan orangtua harus saling bekerjasama untuk mengoptimalkan perkembangan dan pertumbuhan anak usia dini agar nantinya menjadi individu yang berguna, terampil dan mandiri.Namun sangat disayangkan, di daerah - daerah $3 \mathrm{~T}$ (terdepan, terluar, tertinggal) masih banyak orangtua yang belum memahami pentingnya pendidikan untuk anak usia dini, banyak diantaranya anak - anak yang berada di massa golden age kurang mendapat pendampingan untuk belajar. Tuntutan hidup dengan wilayah topografi berbukit - bukit cocok dijadikan untuk perkebunan atau pertanian, sehingga banyak orangtua yang dari pagi hingga sore berada di kebun bahkan ada yang berhari - hari berada di kebun.Kondisi seperti itu yang berlangsung terus menerus menyebabkan kurang berkembangnya aspek - aspek perkembangan pada anak.

Perkembangan pada anak bisa saja dioptimalkan melalui kegiatan pembelajaran di Taman Kanak - Kanak, namun terbatasnya keberadaan TK yaitu hanya ada satu TK yang berada di kecamatan.Kondisi antar kampung yang satu dengan lainnya sangat berjauhan.Hal tersebut menjadikan para orang tua langsung menyekolahkan anak - anak di bangku Sekolah Dasar.Beberapa anak kelas 1 SD $\mathrm{N} \quad 10$ Terangun ada yang berusia kurang dari lima tahun dan banyak yang berusia kurang dari enam tahun. Telah disebutkan diatas, minimnya pengawasan, pendampingandan pemberianstimulus oleh orang dewasa kepada anak menyebabkan kurang berkembangnya perkembangan - perkembangan pada anak. Salah satu nya yaitu kurang optimalnya perkembangan bahasa.

Bahasa merupakan salah satu aspek perkembangan yang tidak kalah penting, dikarenakan bahasa merupakan modal dasar bagi anak untuk dapat berinteraksi dengan orang lain. Tujuan perkembangan bahasa anak dalam kurikulum berfokus pada keterampilan mendengarkan, berbicara, membaca, dan menulis. Membaca perlu ditumbuh kembangkan sejak anak usia dini, dengan membaca ilmu yang diperoleh akan lebih banyak dan akan membuat anak memiliki perbendaharaan kata yang banyak sehingga anak mampu berkomunikasi dengan baik. Di lingkungan sekolah pemberian stimulus untuk meningkatkan perkembangan bahasa dapat dilakukan dengan kegiatan belajar yang menyenangkan.Diharapkan perkembangan bahasa anak di SD N 10 Terangun dapat berkembang dengan baik.

\section{Perkembangan Bahasa Anak}

Perkembangan bahasa pada anak anak di SD N 10 Terangun yang belum berkembang optimal salah satunya yaitu kemampuan membaca permulaan.Anak anak kelas1 Sekolah Dasar yang dilihat dari usia seharusnya masih belajar dan bermain di bangku Taman Kanak - Kanak, namun karena banyaknya faktor di antaranya tidak adanya Taman Kanak Kanak di setiap perkampungan, jauhnya jarak antar kampung dengan kecamatan, mayoritas penduduk atau orang dewasa bekerja di kebun, dan keinganan anak untuk sekolah walaupun usia belum memenuhi untuk duduk di bangku Sekolah Dasar.

Sekolah Dasar pada umumnya sudah mewajibkan semua peserta didik untuk sudah pandai membaca, menulis, menyimak dan bercerita.Namun tidak 
dengan anak - anak kelas 1 SD N 10 Terangun, yang mayoritas anak - anak kelas 1 belum mampu membedakan huruf dengan bunyi huruf "a" sampai " $z$ ", belum mampu membedakan bentuk yang mirip,misalnya m" dengan " $n$ " " $p$ " dengan "b", dan sebagianya. Terbatasnya buku buku untuk anak - anak, sedikitnya media pembelajaran, terbatasnya lembar kerja anak dan teknik mengajar guru yang kurang menarik bagi anak yaitu anak diminta mengulang menulis huruf yang sudah di contohkan oleh guru menyebabkan kebosanan pada anak. Secara usia belum diwajibkan untuk pandai membaca, namun tuntunan sekolah atau kebijakaan sekolah mengharuskan mereka harus pandai membaca.

Masalah yang ditemui di sekolah yaitu, satu hingga tiga dari sepuluh anak kelas satu Sekolah Dasar, anak sudah mampu menyebutkan huruf - huruf (menyebutkan dalam bentuk nyanyiian) namun belum bisa membedakan lambang huruf. Pada saat proses membaca permulaan tersebut, mengalami keterhambambatan maka untuk menuju ke proses perkembangan selanjutnya yaitu kemampuan anak dalam menulis akan mengalami kendala.

\section{Pengertian Membaca}

Membaca adalah bahasa lisan yang merupakan kegiatan dari fungsi mata dalam menerima rangsangan, yang kemudian diteruskan ke otak untuk diproses kemudian dikirim kembali dalam bentuk ucapan atau bunyi (Nano Sunartyo, 2006: 51). Nurbiana Dhieni, dkk (2005: 5.3) juga menyebutkan bahwa "kegiatan membaca merupakan suatu kesatuan kegiatan yang terpadu yang mencakup beberapa kegiatan seperti mengenali huruf dan kata-kata, menghubungkannya dengan bunyi, maknanya serta menarik kesimpulan mengenai maksud bacaan". Berdasarkan pengertian diatas, dapat ditegaskan bahwa membaca adalah kemampuan mengenali huruf dan kata - kata yang merupakan aktifitas dari indra pengelihatan dan kemudian di proses oleh otak. Kegiatan membaca mencakup pengenalan huruf, bunyi dari huruf atau rangkaian huruf.

Tahapan keterampilan membaca anak menurut Munawir Yusuf (2005: 144-147) dibagi menjadi empat tahapan, yaitu: tahap pertumbuhan kesiapan membaca, tahap awal belajar membaca, tahap perkembangan keterampilan membaca, dan tahap penyempurnaan keterampilan membaca. Tahap awal belajar membaca, dimulai dari anak mulai mengenal dan memahami kata - kata, setelah itu anak mampu membedakan kata - kata, pada awalnya anak usia dini yang belum pernah mendapat kesempatan untuk diperkenalkan dengan huruf, anak akan mengalami kesulitan untuk membedakan huruf, sehingga proses membaca dapat berlangsung lambat.

Pada tingkat awal membaca, anak belajar menguasai huruf vokal dan konsonan serta bunyinya.Anak belajar bahwa huruf i memberikan suara /i/, huruf a memberikan suara /a/, huruf $b$ memberikan suara /beh/, huruf $n$ memberikan suara /en/, dan sebagainya (Munawir Yusuf, 2005:162).

Menurut Permendiknas No. 58 Tahun 2009 tentang Standar Pendidikan Anak Usia Dini, tingkat pencapaian perkembangan anak usia 5-6 tahun pada lingkup perkembangan keaksaraan yaitu sebagai berikut menyebutkan simbolsimbol huruf yang dikenal, mengenal suara huruf awal dari nama benda-benda yang ada di sekitarnya, menyebutkan kelompok gambar yang memiliki bunyi atau huruf awal yang sama, memahami hubungan antara bunyi dan bentuk huruf, membaca nama sendiri, menuliskan nama sendiri.

Berdasarkan pengertian diatas dapat disimpulkan bahwa membaca awal merupakan kemampuan anak membaca huruf vocal dan konsonan, meyebutkan 
symbol huruf, memahami hubungan antara bunyi dan bentuk huruf hingga bisa membaca nama sendiri dan menuliskan nama sendiri

Munawir Yusuf (2005: menjelaskan bahwa terdapat dua macam pendekatan dalam mengajarkan membaca permulaan, yaitu pendekatan berdasarkan simbol dan pendekatan berdasarkan makna.Pendekatan berdasarkan simbol lebih menekankan pada keteraturan antara huruf dengan bunyi, dengan tujuan agar anak mampu mengucapkan huruf apapun yang tertulis, meskipun tidak berupa kata. Pendekatan ini dimulai dengan pengenalan nama huruf dan bunyinya, kemudian menggabungkan huruf menjadi suku kata, suku kata menjadi kalimat, dan seterusnya.

Kemampuan membaca permulaan dimulai dari kegiatan menebalkan huruf, menebalkan huruf yang dibuat melalui lembar kerja anak, dimana dalam lembar kerja tersebut terdapat garis titik - titik yang dapat dihubungkan dan membentuk lambang huruf.

\section{Implementasi}

Jenjang Sekolah Dasar merupakan pijakan awal dalam aspek kemampuan perkembangan yang lain. Masalah yang terjadi pada anak - anak kelas 1 Sekolah Dasar SD N 10 Terangun, 8 dari 10 anak belum dapat mengenal atau membedakan huruf, baik itu huruf vokal maupun konsonan.Belum optimalnya perkembangan bahasa pada anak dapat menjadi hambatan bagi perkembangan aspek - aspek perkembangan yang lainnya.Pendidik berupaya mengenalkan membaca secara tepat dan aman.

Kegiatan pembelajaran membaca permulaan dilakukan dengan guru menulis satu huruf di papan tulis kemudian menyebutkan bunyi huruf tersebut bersama - sama. Guru memberikan titik - titik huruf pada selembar kertas kemudian anak menebalkan huruf - huruf tersebut.
Kegiatan tersebut dilaksanakan berulang ulang.Pengulangan dalam menebalkan huruf dapat membiasakan anak mengenal huruf - huruf dan pada kegiatan pembelajaran yang lain, anak diminta untuk menyebutkan dan menulis huruf tersebut pada buku tulis yang sudah dibagikan.Selain menulis di atas buku, kegiatanmembaca permulaan juga dilakukan dengan menghubungkan garis putus-putus yang membentuk pola suatu huruf menggunakan LKA, maupun.Setelah selesai mengerjakan, guru mengajak anak untuk membaca kembali apa yang sudah ditulis anak.

Kegiatan pembelajaran diselingi dengan mewarnai gambar - gambar, sehingga anak tidak mudah bosan dan mudah lelah.Pada saat kegiatan menebalkan huruf anak - anak lebih berantusias dengan menebalkan dengan berbagai macam warna.Jumlah guru yang hanya ada satu di Kelas dengan kondisi siswa tersebut membuat situasi pembelajaran kurang dapat dikondisikan.Seorang guru diharuskan untuk mampu mengkondisikan kelas serta mampu untuk memberikan materi pembelajaran di waktu yang bersamaan.

Kegiatan membaca juga dilakukan pada saat jam istirahat, anak - anak memilih menebalkan huruf dan belajar mengenal huruf kemudian di eja dan dapat membentuk suatu kata. Guru memberikan latihan membaca satu persatu secara bergantian. Pada saat tertentu guru memberikan kartu kartu berisi huruf titik titik kemudia setelah selesai menebalkan anak menulis kembali huruf yang ditebalkan.

Kegiatan yang lain yang disukai anak anak ketika menebalkan huruf, anak suka sekali menebalkan huruf kemudian menuliskan huruf tersebut di papan tulis. Kegiatan membaca permulaan seharusnya dilakukan dengan kegiatan yang menyenangkan dan menarik.Kegiatan tersebut dapat dikreasikan sesuai dengan kreativitas guru, misalnya dengan 
menggunakan maupun memodifikasi media pembelajarannya. Media pembelajaran yang dapat digunakan untuk pengenalan huruf tidak hanya berupa buku, majalah, pensil, spidol, crayon, ataupun lembar kerja anak (LKA), akan tetapi guru dapat menggunakan media yang lain, baik audio, visual, maupun audio visual. Media audio dapat berupa rekaman suara melalui radio maupun tape recorder.Media visual dapat berupa gambar, media grafis, media model maupun media realia.Media audio visual berupa televisi, film, video, dan lain-lain (Cucu Eliyawati, 2005:114).

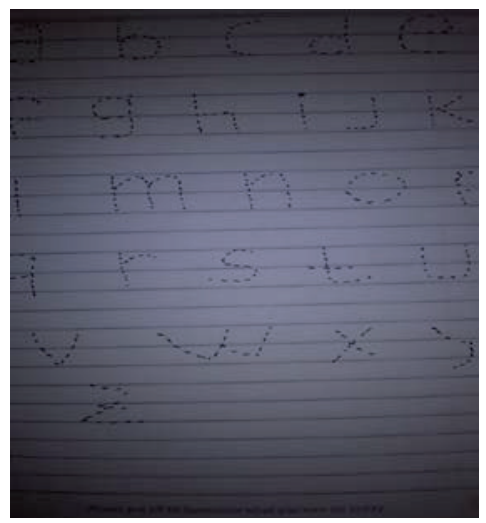

Gambar 1

Lembar titik - titikuntuk menebalkan huruf, lembar kegiatan yang disukai anak.

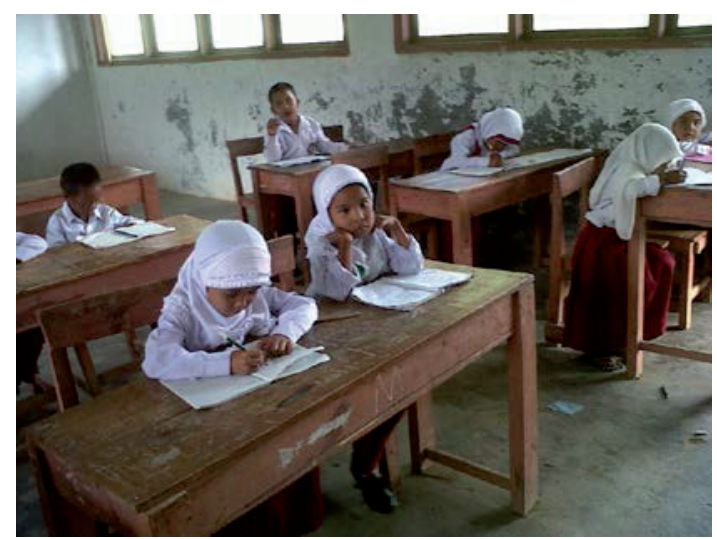

Gambar 2.

Kegiatan menebalkan huruf di atas buku masing - masing peserta didik.

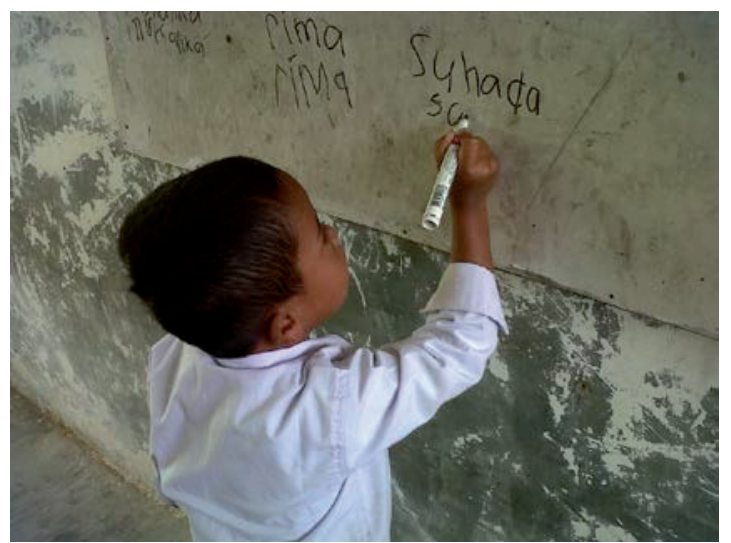

Gambar 3.

Kegiatan anak setelah menebalkan huruf anak senang menulis di papan tulis.

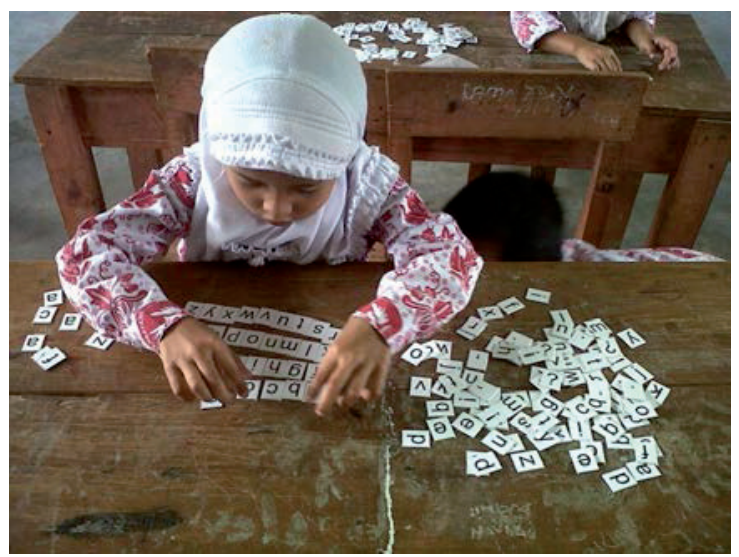

Gambar 4.

Anak sudah mengenal huruf kemudian disusun menjadi kata

\section{KESIMPULAN}

Membaca permulaan dapat dilakukan dengan kegiatan yang menarik dan tidak membosankan.Kegiatan menebalkan huruf menggunakan bermacam - macam variasi dapat menjadikan anak lebih mudah menerima dan mengenal macam - macam lambang huruf.Semakin banyaknya lambang huruf yang diterima anak, maka kosa kata yang anak miliki juga akan semakin kaya. Lambang huruf yang sudah dipahami anak, akan memudahkan anak dalam menemukan kata - kata baru. 


\section{DAFTAR PUSTAKA}

Cucu Eliyawati. (2005). Pemilihan dan Pengembangan Sumber Belajar Untuk Anak Usia Dini. Jakarta : Depdiknas

Harun Rasyid, dkk. (2009).Asesmen Perkembangan Anak Usia Dini. Yogyakarta: Multi Pressindo

Munawir Yusuf. (2005). Pendidikan Bagi Anak Dengan Problema Belajar. Jakarta: Depdiknas

Nano Sunartyo. (2006). Membentuk Kecerdasan Anak Sejak Dini. Yogyakarta: Penerbit Think

Nurbiana Dhieni, dkk. (2005). Metode Pengembangan Bahasa. Jakarta: Universitas Terbuka 